Meta

Journal des traducteurs

Translators' Journal

\title{
Censorship in Translation: The Dynamics of Non-, Partial and Full Translations in the Chinese Context
}

\section{Zaixi Tan}

Volume 62, numéro 1, avril 2017

URI : https://id.erudit.org/iderudit/1040466ar

DOI : https://doi.org/10.7202/1040466ar

Aller au sommaire du numéro

Éditeur(s)

Les Presses de l’Université de Montréal

ISSN

0026-0452 (imprimé)

1492-1421 (numérique)

Découvrir la revue

Citer cet article

Tan, Z. (2017). Censorship in Translation: The Dynamics of Non-, Partial and Full Translations in the Chinese Context. Meta, 62(1), 45-68.

https://doi.org/10.7202/1040466ar

\section{Résumé de l'article}

Cette recherche explore comment la traduction de certains genres littéraires en Chine est passée, au cours de l'histoire, de " non-traduction » (c.-à-d. " traduction non faite aussi bien que faite mais pourtant strictement interdite compte tenu des conditions censoriales ») à traduction " partielle » ou " complète/presque complète ", qui s'accorde avec le contexte de la pratique variable exigée par la politique de censure du pays. Notre analyse commence par une vue d'ensemble de la relation complexe entre censure et traduction, suivie par la conceptualisation d'une typologie de traduction sous la censure. Cette discussion initiale permet de redéfinir les traductions spécifiques, y compris les traductions autrefois absentes (par exemple avant la Révolution de 1949 ou avant la Révolution culturelle) qui étaient initialement considérées comme " non-traductions » et qui, pourtant, sont devenues plus tard des traductions " partielles » ou « complètes/presque complètes » sous les opérations censoriales plus laxistes. Nous tentons d'illustrer de tels changements par une discussion en profondeur sur la nature dynamique de la fidélité de traduction en fonction des propriétés résistantes au changement et des priorités évolutives de la censure. En illustrant nos arguments, nous offrirons des exemples qui sont tirés des études de cas de trois traductions bien connues, qui sont affectées par la politique de censure : On China (Kissinger 2011), Lolita (Nabokov 1991) et The Good Earth (Buck 1960) qui incarnent selon nous le degré d'évolution de la fidélité de traduction ( " non- ", " partielle » et « complète/presque complète ») dans le contexte chinois.
Ce document est protégé par la loi sur le droit d'auteur. L'utilisation des services d'Érudit (y compris la reproduction) est assujettie à sa politique d'utilisation que vous pouvez consulter en ligne.

https://apropos.erudit.org/fr/usagers/politique-dutilisation/ 


\title{
Censorship in Translation: The Dynamics of Non-, Partial and Full Translations in the Chinese Context
}

\author{
ZAIXI TAN \\ Hong Kong Baptist University \\ thtan@hkbu.edu.hk
}

\section{RÉSUMÉ}

Cette recherche explore comment la traduction de certains genres littéraires en Chine est passée, au cours de l'histoire, de «non-traduction» (c.-à-d. «traduction non faite aussi bien que faite mais pourtant strictement interdite compte tenu des conditions censoriales ») à traduction «partielle» ou «complète/presque complète», qui s'accorde avec le contexte de la pratique variable exigée par la politique de censure du pays. Notre analyse commence par une vue d'ensemble de la relation complexe entre censure et traduction, suivie par la conceptualisation d'une typologie de traduction sous la censure. Cette discussion initiale permet de redéfinir les traductions spécifiques, y compris les traductions autrefois absentes (par exemple avant la Révolution de 1949 ou avant la Révolution culturelle) qui étaient initialement considérées comme «non-traductions » et qui, pourtant, sont devenues plus tard des traductions «partielles» ou «complètes/ presque complètes » sous les opérations censoriales plus laxistes. Nous tentons d'illustrer de tels changements par une discussion en profondeur sur la nature dynamique de la fidélité de traduction en fonction des propriétés résistantes au changement et des priorités évolutives de la censure. En illustrant nos arguments, nous offrirons des exemples qui sont tirés des études de cas de trois traductions bien connues, qui sont affectées par la politique de censure: On China (Kissinger 2011), Lolita (Nabokov 1991) et The Good Earth (Buck 1960) qui incarnent selon nous le degré d'évolution de la fidélité de traduction (《non-», «partielle» et «complète/presque complète») dans le contexte chinois.

\footnotetext{
ABSTRACT

This research focuses upon how the translation of certain types of literature in China evolved historically: from 'non-translations' (i.e., 'translations' unmade as well as made and yet strictly forbidden under given censorship conditions) to 'partial' or 'full/near-full' translations set against the backdrop of changing practices required by the country's censorship policies. My analysis begins with an overview of the multi-faceted interface between censorship and translation, followed by the conceptualization of a typology of translations under censorship. This initial discussion, in turn, allows me to resituate specific translations, including the once absented translations of earlier times (i.e., prior to the 1949 Revolution or prior to the Cultural Revolution), which were initially taken at face value as 'non-translations' and yet which, later on, became 'partial' or 'full/near-full' translations under the country's subsequently more relaxed censorial operations. I attempt to illustrate such shifts by means of in-depth discussion of the dynamic nature of translational commitment in connection with the change-resistant properties and evolving priorities of censorship. In illustrating my arguments, I will draw specific examples from case studies of three well-known censorship-affected translations - i.e., On China (Kissinger 2011), Lolita (Nabokov 1991) and The Good Earth (Buck 1960), which, I argue, epitomise the shifting degrees of translational commitment ('non-,' 'partial' and 'full/near-full') as they occurred in the Chinese context.
} 


\section{RESUMEN}

El presente estudio se enfoca en la evolución histórica en China de las traducciones de ciertas obras literarias extranjeras: de "no traducciones" (traducciones no hechas o prohibidas por la censura) a "traducciones parciales" o "traducciones completas o casi completas" bajo las cambiantes políticas de censura del país. El análisis comienza con una presentación sobre las interfaces multifacéticas entre la censura y la traducción, y una distinción entre diferentes tipos de traducción bajo la censura. Esta discusión, a su vez, permite resituar algunas traducciones específicas, incluyendo las obras traducidas pero ausentes de las épocas anteriores (antes de la Revolución de 1949 o de la Revolución Cultural de 1966), que inicialmente se toman como parte de "no traducciones", y que debido a la relajación de las políticas de censura se convierten en obras "parcialmente" o incluso "completamente o casi completamente" traducidas. Este estudio apunta a ilustrar tales cambios a través de una profunda discusión sobre la dinámica del compromiso de traductores combinándola con la naturaleza cambiante y permanente de las políticas de censura. A fin de argumentar las opiniones del autor sobre el "compromiso de traductores" (incluyendo "no compromiso", "compromiso parcial" y "compromiso completo"), en el presente artículo se toman como ejemplos tres obras traducidas muy conocidas y afectadas por la censura: On China (Kissinger 2011), Lolita (Nabokov 1991) y The Good Earth (Buck 1960).

\section{MOTS-CLÉS/KEYWORDS/PALABRAS CLAVE}

censure, autocensure, non-traduction, traduction partielle, traduction complète, dynamique, contexte chinois

censorship, self-censorship, non-translation, partial translation, full translation, dynamics, Chinese context

censura, auto-censura, no traducción, traducción parcial, traducción completa, dinámica, contexto chino

\section{Introduction}

As pointed out in Tan (2015: 313-314), governmental censorship in China can be traced back to the times of Qin the First Emperor of China (259 BCE-210 BCE) who ordered books he did not like to be burned and scholars buried alive for owning forbidden books. In much the same way in the Western world, 'suspicious books' were burned by the Council of Ephesus in the fifth century; and William Tyndale was burned to death by church authorities in 1536 in England, as was Étienne Dolet in 1546 in France. In the Chinese context, ever since Qin's times, there has virtually been an unbroken line of censorship running through history, differing from dynasty to dynasty only in the kind of literature which was allowed or forbidden, and in the scale on which censorship was exercised. This unbroken line of history has apparently run to modern and contemporary times, through the People's Republic of China (PRC). Since 1949 when the socialist state was founded, the PRC has endured various modes of censorship, all bearing either directly or indirectly on the activity of translation. As part of the author's on-going research project on Chinese censorship and translation, the present paper aims to offer a further discussion of some of the important issues concerning this topical area. 


\section{The multi-faceted interface between censorship and translation}

Censorship and translation "mark opposite points on the spectrum of signification: if translation works to raze boundaries between text and reader, censorship strives to raise them" (Escolar 2011: 1). On the other hand, however, there are innumerable locations, whether political, linguistic or cultural, at which the two may meet and shake hands. This is because they can both be defined as "a form of manipulative rewriting of discourses by one agent or structure over another agent or structure, aiming at filtering the stream of information from one source to another culture" (Billiani 2007: 3), and because both censors and translators can be regarded as "gatekeepers, standing at crucial points of control, monitoring what comes in and what stays outside any given cultural or linguistic territory" (Holman and Boase-Beier 1999, cited in Merkle 2002: 9). The implication of the first scenario, where translation "works to raze boundaries between text and reader" and censorship "strives to raise them," is that the former is an activity that may be hindered or prohibited by the latter. In contrast, the implication of the second, that a translator is by nature also a 'censor' or 'gatekeeper,' must be approached with caution. For there exists a major difference between them with regard to agency in the 'gatekeeping' process. In the case of the censor-gatekeeper, one exercises manipulative power over somebody else's work (e.g., by checking and preventing the inflow of 'unwelcome' literature of the Other); whereas in the case of the translator-gatekeeper, manipulation is realised through translatorial regulation of both somebody else's (i.e., the author's) work and the translator's own (e.g., by making additions, omissions and modulations or changes in the translation act). In other words, the 'gatekeeper' in the translator is not quite the same as the 'gatekeeper' in the censor, as the translator-gatekeeper tends to be, or is often made or coerced (by the censor-gatekeeper) to be, self-targeting (i.e., self-censoring) while the censor-gatekeeper always targets entities other than the self - except, of course, when one also regards a government's control or regulation of its own information release system as an act of censorship, as most, if not all, governments in the world restrict the release of information for 'national security' or other reasons, either to foreign countries or its own people.

What is presented here is a twofold point. First, between censorship and translation, a dialectic relationship exists, in the sense that the two are both different and the same in their basic properties. Second, as to their being the same, that 'sameness' must be carefully differentiated, on two levels:

(a) teleologically, the 'gatekeeping' in the censor means checking and blocking the inflow of foreign information, especially information considered 'subversive' or 'potentially subversive' to the target culture, whilst that in the translator means ensuring that the information in question (or some portion of it) eventually enters the target culture; and

(b) operationally, the act of 'gatekeeping' (in translation) for the censor involves something the censor imposes on the translator, whilst that for the translator is essentially something self-imposed.

Given this multifaceted interface, censorship and translation are indeed more intrinsically related to each other than one may wish to think. It is from the perspective of this intrinsic, multifaceted relationship that this paper will proceed to examine how, in the Chinese translational context, censorship (self-censorship included) 
determines the extent to which the translator is committed to his/her author, or how fully, partially, or not at all, a translation may be made. Building from the basic argument I have previously developed (Tan 2014), this present study will mainly focus on how the translation of certain types of literature in China shifted historically: from 'non-' to 'partial' or 'full/near full' translations set against the backdrop of changing practices required by the country's censorship policies. To illustrate my points, I will draw specific examples from case studies of three well-known censorship-affected translations: On China (Kissinger 2011), ${ }^{1}$ Lolita (Nabokov 1991) ${ }^{2}$ and The Good Earth (Buck 1960) ${ }^{3}$ which may arguably be considered representative cases of the shifting degrees of translational commitment ('non-', 'partial' and 'full/near-full') as they occurred in the Chinese context.

\section{Conceptualizing a typology of translations under censorship}

Broadly speaking, as was proposed previously (Tan 2014: 192), in the Chinese context, we can distinguish three types of censorship- and/or self-censorship-affected translatorial commitment, corresponding to the various traditional concepts of 'translatorial faithfulness,' i.e., 'full,' 'partial' and 'non-': full translatorial 'faithfulness' results when the translator is fully committed to his/her author where the work being translated falls entirely within the category of 'fully translatable' foreign literature, defined in turn as being completely 'harmonious' in relation to existing Chinese constitutional laws; the second type of translatorial commitment is where the translator is partly faithful to his/her author, so that changes are made of the intentions of the author in order that the target text does not conflict with the censor; and thirdly, where censorship blocks everything, no translation is made or allowed to be made, hence implicating no translatorial commitment. Whether or not such a nontranslator-author relationship is a permanent situation or can somehow emerge at a later point in time, thus converting non-translations to translations, partial or full, is determined by the changing censorial conditions of the given context.

Determined by changing censorial conditions is also the status of other types of translatorial commitment including the 'partial' and 'full.' All of this, indeed, would point to the dynamics of the various types of the resulting translations, which we will address in the next section. But before we proceed to that, further discussion of the tripartite typology of such censorship- and/or self-censorship-affected translations is in order.

At one end, i.e., the extreme end, of censorship over a target piece of literature intended for translation there is the prohibition or banning of that literature, which, often as a major post-censorship happening in China, means there is to be no translation made at all. Therefore, it is logical for our typological discussion to start with this extreme end, where the category of what I would call 'non-translations' is involved. As the name suggests, 'non-translations' are 'translations' that have not been made, or 'translations' that do not exist at all. Of course, if a 'translation' has not or has never yet been made, or if it is non-existent, then there is no 'translation' to talk about in the first place, and it would seem appropriate to simply call such an 'empty' entity a 'zero' entity, or such a non-existent translation a 'zero translation.' However, if one goes deeper beneath the various 'empty,' 'zero' or 'non-existent' entities, one would find that there are two distinct kinds of underlying causes: one being 
censorship-related, and the other not having anything to do with censorship. The point we aim to make here is that, while both share the meaning of 'being empty or non-existent,' 'non-translations' and 'zero translations' must be understood as two essentially different concepts. By definition, a 'zero translation' situation is where there is no translation of a given source text and the fact of there being no translation of the given source text is purely the outcome of causes unrelated to anything political, ideological, moral or the like, such as a source text simply not being known to or not having attracted the attention of any potentially interested translator. In other words, the absence of translation is not deliberate, not intended and not motivated. For example, as may be noted from Table 1 below, Robert Lawrence Kuhn's The Man Who Changed China: The Life and Legacy of Jiang Zemin (2004) has a 'partially' translated Chinese version in the PRC, but there is no Hong Kong or Taiwan version. As there is no reason to believe that Hong Kong or Taiwan would censor any translation of the book there, absence of such a translation is but a case of 'zero translation.' In this connection, it can be said that wherever a source text does not have a corresponding translation in a given target language a 'zero translation' would result, except where the given translational absence is deliberate, intended or motivated out of causes related to censorship and/or self-censorship. Broadly speaking, the 'zero translation' concept may also cover situations where some segment of a source text (e.g., a passage, a sentence or even a word) is missing from a translated target text, provided, of course, that this is the result of unintended behaviour on the part of the translator. If, on the other hand, the absence of translation results from deliberate translatorial behaviour, then a zero translation is no longer a 'zero translation' but a 'non-translation.' It must be noted that though they appear at surface value quite similar to each other, the two terms, and of course their corresponding concepts as well, are not supposed to be interchangeable. When explained in Chinese, 'nontranslation' takes the sense of '缺席翻译/缺席译本/缺译' [=absented translation] whilst 'zero translation' 零翻译' / '零译本” / “零译' / ‘未译' [=(text) not translated]. In more specific terms, 'non-translations' can be defined as falling into any one of the three groups or sub-categories, i.e.:

(a) Translations that have not, or never yet, been made but whose absence is significant as they are the result of state/government censorship and/or the translator's (or publisher's, editor's or commissioner's) self-censorship, on various grounds, political, ideological, religious, moral or ethical, socio-cultural, and even stylistic or linguistic. In the context of the PRC, the reason why non-translations of this category are so branded is that they are 'anti-China,' 'anti-Communism,' 'antiChinese Constitution,' 'politically subversive,' 'ideologically reactionary,' 'morally unhealthy,' 'ethnically separatist,' 'harmful to national security,' 'obscene,' 'violence instigating,' 'anti-harmonious society,' and so forth. Typical examples include 'unfriendly,' 'unwelcome' or 'hostile' materials on top-Chinese leadership and on such sensitive events or issues as the Tiananmen Square protests of 1989, the government-banned Falungong Cult, and Taiwan, Tibetan or Xinjiang independence, to name but a few that significantly remain at issue today.

(b) Translations that may have been made at an earlier time, but are forbidden to circulate at a later time, usually under changed censorship conditions, so that the earlier-made translations in question are turned into 'non-translations,' i.e., 'absented or suppressed translations' as they may be alternatively called under such circumstances. Then subsequently, with the change of conditions yet again, the 
given 'non-translations' or 'absented/suppressed translations' may once more become 'permissible' or 'reinstituted'/'unsuppressed' translations. The best-known example in this case is the shifting status from translation to non-translation, and from non-translation back to translation, of D. H. Lawrence's Lady Chatterley's Lover in Chinese over a period of some 50 years under the conditions of the Chinese censorial system - a point we shall revert to in the next section.

(c) Translations that have not been made or allowed to be made in the context of the PRC, but that may have been made and may freely circulate in other contexts, such as in Hong Kong and Taiwan. Examples of this group are many as they tend to coincide with the kind of non-translations of the first group described above, such as Mao's Great Famine: The History of China's Most Devastating Catastrophe, 19581962 (Dikotter 2010) translated and published in Hong Kong (2011) and later also in Taiwan (2012), The New Chinese Empire: And What It Means for the United States (Terrill 2003) translated and published in Taiwan (2004), and Fifty Shades of Grey (James 2011) translated and published in Taiwan (2012). Very often, the non-translations of this group, so considered in the context of the PRC, found to be translations in other Chinese language contexts such as Hong Kong, Macao, Taiwan or Singapore, may have copies smuggled across the border into the PRC one way or another, hence converting a non-translation into a translated situation, albeit only for a very limited, privileged audience, i.e., an audience that may somehow have access to censored literature from beyond the borders of the PRC.

The second general category of our tripartite typology involves what we would term 'partial translations.' By definition, partial translations are "translations that contain omissions, shifts of meaning or modulation of overall author-tone that necessarily change the intentions (however partially) of the author" (Tan 2014: 197). These omissions, shifts and modulations, as well as additions, are sometimes made in order to comply with overt state/government censorial requirements, and sometimes under the force and effect of the translator's (or editor's and publisher's) selfcensorship and in an attempt to conform to the country's dominant ideology as well as social conventions so that potential conflict with government censors can be avoided and their translational products can be safely published and marketed. Translations that fall into this category in the Chinese context include those whose source texts have in principle passed the scrutiny of state/government censors and are considered 'translatable' in principle but translational modulations must be made where the ST content is regarded as 'sensitive' and 'unacceptable' to the target culture. Among the more recent examples of such 'partly (self-)censored Chinese translations' are those of John Leighton Stuart's Fifty Years in China - The Memoirs of John Leighton (English original in 1954, PRC version in 1982); Dick Wilson's Zhou Enlai: A Biography (English original in 1984, PRC version in 1990); Hillary Clinton's memoir Living History (English original in 2003, PRC version in 2003); Robert Kuhn's The Man Who Changed China: the Life and Legacy of Jiang Zemin (English original in 2004, PRC version in 2005); Henry Kissinger's On China (English original in 2011, PRC version in 2012) and Ezra F. Vogel's Deng Xiaoping and the Transformation of China (English original in 2011, PRC version in 2013). In all of these, censorship- and/ or self-censorship-driven additions, omissions, shifts or modulations are abundant. The two quotes below from “The translator's preface” by Feng Changhong (封长虹 1990: 2) and “The translator’s remarks” by Cheng Zongjia (程宗家1982: 1-2) to their translations of Dick Wilson's Zhou Enlai and John Leighton Stuart's Fifty Years in China respectively, are representative of the general mindset of the self-censoring, 
self-modulating translator in the PRC context and they well explain why and how additions, omissions, shifts or modulations are made so that a given ('partial') translation may not conflict, at least not too explicitly, with government position and be 'properly' received by the Chinese audience:

However, as someone from the West [referring to the author of the book being translated], the author has constraints and limitations of his own in terms of his points of view, selection of the subject matter, ways of thinking and angles from which to analyse problems. Because he is not Chinese, he would not have been able to accurately understand everything that happened in China. The data he used in the writing cannot have been entirely reliable and his points of view cannot have been free from personal subjectivity and arbitrariness. But in my attempt to keep the original form and style of the book, I have made appropriate adjustments only to those places that looked too absurd and strange while leaving some of the odd plots and thoughts to the judgement of the readers. In the meantime, I have deleted some of the annotations in the source text which I considered unnecessary and added some that I thought might help the Chinese reader better understand the content of the book. (Abstracted from Feng Changhong 1990 "The translator's preface" to the A Translation of Dick Wilson's Zhou Enlai: A Biography; my translation. ${ }^{4}$ )

Leighton Stuart's narrative of China was biased, distorting, hence very reactionary. However, given the context of today when we are making efforts to study the history of Sino-American relations, the hypocritical nature of the undertakings of foreign preachers in China, the history of conspiracy and collaboration between the American government and Chiang Kai-shek, and the inevitability of the downfall of Chiang's regime, the author of these memoirs has provided us with some useful material from an adverse perspective. In this light, the translation is a faithful reproduction of the original, except for the omission of the author's own foreword, the introduction by $\mathrm{Hu} \mathrm{Shi}$ and some individual passages that trumpet praises of Chiang Kai-shek ... (Abstracted from "The translator's remarks" by Cheng Zongjia to the Chinese version of John Leighton Stuart's Fifty Years in China: The Memoirs of John Leighton; my translation. ${ }^{5}$ )

It must be noted that, in broad terms, 'partial translations' should also include those that are not necessarily driven by censorship and/or self-censorship, such as those with unintentional (mainly linguistically or stylistically motivated) omissions or changes. But for this research such would be described as 'incomplete' or simply 'inaccurate' translations without censorship implications, while 'partial translations,' as discussed above, would be reserved to refer to translations containing omissions and modulations driven by censorship and/or self-censorship.

The third category, i.e., that of 'full translations,' covers translations that result from full/near-full translatorial commitment to the source text, in the sense that everything in the source text can be, and often is, accurately transferred to the target text, or translations that contain no or nearly no censorship-driven or self-censorship motivated additions, omissions or changes of the author's meaning. As pointed out previously, with 'full translations,' the material being translated is considered completely 'translatable' and fits in 'harmoniously' with Chinese laws. Under such circumstances, the translator is not primarily concerned with the ideology or the political orientation of the work being translated, but with translation strategies and techniques on an operational level. In other words, when additions, omissions and modulations are made, they are to ensure that the target text is linguistically or stylistically understandable, readable and acceptable in the target language. Whether 
or not the content of the translated text is politically or otherwise sensitive is basically not at issue for the translation being made. Most Western classics from the ancient to the present times fall into this broad category.

In sum, under the current conditions of the PRC, whose constitutional laws provide for the exercise of overt translational censorship (which, consequently, is often joined by the translator's self-censorship), the activity of translation is bound to involve various kinds of translatorial commitment. These would, in turn, result in various types of translations, ranging from 'non-' to 'partial' to 'full/near-full.' In order for such a tripartite typology to be more fully understood, two further clarifications need be made. First, this tripartite categorisation of the censorship- and/or self-censorshipaffected translatorial commitment and translational faithfulness must be understood on a broad basis. That is, the three concepts will each cover a wide semantic or conceptual range. For example, as seen above, 'non-translations' can be understood as falling into three specific sub-categories. Similarly, 'partial' and 'full' translations are both also broad categories, in the sense that they each do not comprise just one type of translation but an infinite number of translations that may be of a varied degree of 'partialness' or 'fullness.' For instance, the PRC versions of Hillary Clinton's Living History and Henry Kissinger's On China can both be considered 'partly censored' or 'partly self-censored,' hence both being 'partial translations,' but obviously the two translations differ from each other in the extent to which they each have been affected by censorship and/or self-censorship in the translation and publication process. The same must also be true of all 'full/near-full translations,' where whether or not they are of ancient or modern authors, or whether they are philosophical or literary works, different kinds of 'fullness/near-fullness' surely exist, with some emphasising 'fullness/ near-fullness' in content while others do so in style or form, and so on.

The second clarification to be made bears partly on the first and partly on a need to emphasise that there is no absolutely clear-cut boundary between what is 'partial' and what is 'full/near-full' in translation. Just as different degrees of 'partialness' exist with what can be defined as a 'partial translation,' and different degrees of 'fullness/ near-fullness' with a 'full/near-full translation,' so is it difficult to differentiate one from the other in the border regions of 'partial' and 'full/near-full translations.' This is because sometimes it is not easy whether to describe certain given translational additions, omissions and modulations as motivated by censorship and/or self-censorship, or simply as the outcome of pure translatorial action unrelated to censorship or self-censorship. However, for the sake of descriptive convenience and also to avoid unnecessarily complicating the issue, we shall nevertheless still follow our tripartite typology and categorise censorship- and/or self-censorship-associated translations, rather broadly, as 'non-,' 'partial' and 'full/near-full,' and proceed further to discuss their underlying dynamics along this line of thought in the next section.

\section{The shifting status of 'non-,' 'partial' and 'full/near-full' translations}

Undoubtedly, "censorship goes hand in hand with translation, not only in dictatorial regimes or in a distant past, but also nowadays, and in countries deemed as democratic" (Seruya 2008: xix), and this well depicts the 'absolute,' unchanging nature of censorship over the activity of translation or any other literary and cultural activity for that matter, at any time and in any society. But as we have also noted, the censo- 
rial conditions may change with the overall socio-political and ideological system of a given context, and with them the status of translations, from 'non-' to 'partial' to 'full/near-full translations,' and sometimes the change may even take place in a reverse order, i.e., from 'full/near-full' to 'partial' to 'non-translations.'

The best illustrative example in this case, as mentioned briefly in Section 3, is the shifting status between the translation and non-translation of D. H. Lawrence's Lady Chatterley's Lover. ${ }^{6}$ Its first Chinese version published in 1936, at a time when the English original was itself a banned work in its native land of England, Lady Chatterley's Lover, or “查泰莱夫人的情人 [Chatelai Furen de Qingren]” in Chinese, was first made a non-translation (in the sense of 'absented or suppressed translation') with the founding of the PRC in 1949, on the ground of its being an 'obscene' and 'decadent' work of literature. This 'non-translation' status remained from then onwards, through the 1950s and 1960s right up to the post-Cultural Revolution period when in 1986, inspired by the country's increasingly more liberal policies and the publisher's economically-motivated ambitions, the Hunan People's Publishing House published a new translation (which, in essence, was a republication of the same old version made by the same translator Rao Shuyi/饶述一 published in Shanghai in $1936^{7}$ ). This 'new publication' immediately converted an existing non-translation into a translation. However, for almost the same reason as when the first translation was made a 'non-translation' in the aftermath of the 1949 revolution, hardly had two weeks passed before a strict ban was placed on the circulation of this new publication. With the few sold copies recalled wherever possible, and the more than 300,000 printed but unsold copies either reduced to pulp or sealed and locked up in the publisher's storerooms, the new translation was turned into a new 'non-translation' and the publishing house with the translation's general editor and a few other major figures behind the project were subjected to a harsh penalty, including the general editor's removal from his post and the authorities' severe warning letters for the others. This 'non-translation' status of Lady Chatterley's Lover remained virtually unchanged till 2004, 55 years after its first translation was made a 'non-translation' in the PRC and 18 years after its dramatic change of status from 'non-translation' to 'translation' and then back from 'translation' to 'non-translation,' when a new translation was made by Zhao Susu (赵苏苏) and published by the People's Literature Publishing House (PLPH) in Beijing. Founded in 1951 and hitherto the largest publisher of literary works in China, this state-owned publishing house often functions as a weathervane publisher of the kind of literature that is 'politically, ideologically or morally correct' under the country's censorship system (For a more detailed discussion of the mechanism and operation of the censorship system of the PRC, see Tan 2015: 321-324). More specifically, the publication of Zhao's new translation by the PLPH in 2004 was broadly regarded as an eventual lifting of the ban on what was formerly censored as unpublishable, 'obscene' or 'decadent' foreign works such as Lady Chatterley's Lover. Consequently, as an outcome of this primarily 'morallymotivated' post-censorship, the formerly 'suppressed translation' or 'non-translation' in question, i.e., that of Chatelai Furen de Qingren (Lady Chatterley's Lover), was converted once again to a 'translation,' followed further on by at least 6 other versions in subsequent years, including those made respectively by Feng Tie (冯铁; Henan Literature Press, 2007), ${ }^{8}$ Yang Hengda and Yang Ting (杨恒达, 杨婷; Beijing Yanshan Press, 2008), ${ }^{9}$ Yongmu Beile (雍穆贝勒; China Overseas Chinese Publishing House 
2009), ${ }^{10}$ Heima (黑马; a bilingual version; Yilin Press, 2009; a single-language version; Central Compilation \& Translation Press, 2010) ${ }^{11}$ and Xianzi (先子, Shandong Literature Press, 2010). ${ }^{12}$

An equally well-known example of the 'translation $\rightarrow$ non-translation/suppressed translation $\rightarrow$ translation' shift is of The Good Earth (Buck 1960), which, unlike that of Lady Chatterley's Lover (Lawrence 1928), is a case of a political and ideological nature. Between 1932 and 1936, at least five different translations were made in Chinese, 'partial' or 'full/near-full.' But after the founding of the PRC, with the work being all along criticised by Leftist critics as an 'anti-China' novel because the story it told was considered a 'smearing' of the image of the Chinese peasant and, by extension, the Chinese people, The Good Earth was banned: all translations that had been made before 1949 were no longer allowed to circulate, hence turned into de facto 'non-translations.' This situation continued well after the end of the Cultural Revolution, till 1988 when a new translation was published by the Lijiang (漓江) Press of Guilin, Guangxi Province, in the wake of the official rehabilitation of Pearl Buck herself from being branded as an 'anti-China, U.S. imperialist agent' to 'a friendly American expatriate who knew China well.'13

It must be noted, though, that in spite of there being no lack of cases like the above involving some circular kind of movement between non-translations and translations, the more commonly found cases seem to be a forward-moving, or more or less forward-moving, rather than a circular dynamics, i.e., the change of status being mostly from non-translations to translations. In some cases this forward evolution may only mean 'partial' translations, whilst in other cases 'partial' translations first and then 'full/near-full translations,' and in yet other cases straightforwardly 'full/near-full translations.' For example Animal Farm (Orwell 1945) (4) $^{4}$ was basically a non-translation under Chinese censorship all along until its first ever PRC version appeared in 1988, ${ }^{15}$ followed by 10 other translations in quick succession over a period of 13 years between 2000 and 2013. It was also the case with Lolita (Nabokov 1991) which was not translated into Chinese till 1989, when 5 different versions, all 'partially' made, were published in the same year followed by 3 more 'partial' translations between 1994 and 1997, and one 'full' translation in 2005.

With this discussion of the four cases above involving the dynamics of 'translation $\rightarrow$ non-translation/suppressed translation $\rightarrow$ translation' or straightforward 'nontranslation $\rightarrow$ translation,' let us now turn to a more general view of the translational developments in China during the past 60 and more years. We will first briefly look at the overall statistics via a pie chart and then at a table containing contrastive data on specific examples, before making a follow-up discussion of some of the relations and motives that were involved in the process of translation and censorship:

Overall statistics. The pie chart (Fig. 1) below presents a statistical overview of Chinese translations of English-language literature over the past 60 years in regard to the various categories of 'non-,' 'partial' and 'full/near-full' translations. The figures and percentages in the chart are based on a total of 2,303 translations (i.e., 'non,' 'partial' and 'full/near-full' translations put together) that had been surveyed as of 15 September 2015 in the author's research project. ${ }^{16}$ Though the survey part of the project (after an entire year's intensive work) is nearly finished, there is still the possibility of the pool of data growing somewhat larger, as the project proceeds. However, no matter how much larger the final pool of collected material might become, there 
will not likely be a drastic change in the distribution pattern among the various types of translations, 'non-,' 'partial' and 'full/near-full.' Hence the relative percentages now shown in the chart would likely remain more or less unaltered even when the project is eventually completed in 20 more months' time.

FIGURE 1

Overall statistics on translated English-language literature in the PRC (1949-2015)

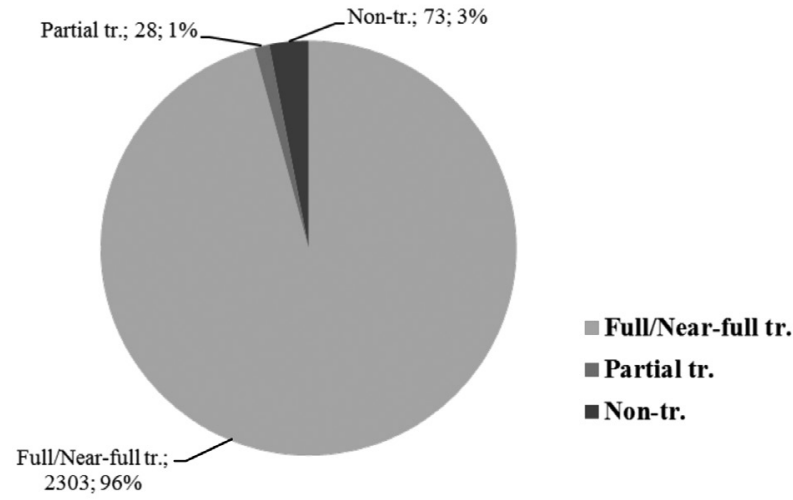

It is important to note that there is a vast difference between the various percentages in the chart, ranging from 3\% for 'non-,' to $1 \%$ for 'partial' and $96 \%$ for 'full/ near-full' translations. The reason for such a difference is twofold. For one, there is no absolute standard for discerning whether a given work not having been translated was owing to censorship and/or self-censorship, hence a case of a non-translation instead of a zero translation. If one factors in the numerous cases where a theoretically 'zero' translation may actually turn out to be a 'non-' translation, then the number of non-translations may grow much larger. For another, the study has found that the $96 \%$ 'full/near-full translations' are in fact overwhelmingly the products of the post-Cultural Revolution - especially the most recent - period, during which time there has been an increasingly more liberal government position on the import and translation of foreign literature, hence making it hitherto the best possible period of the PRC for 'full/near-full translations' to be made in. Therefore, it is no wonder that, because of this encouraging, increasingly more open position of the government in recent years on the translation and importation of 'alien' literature, the proportion of 'full/near-full translations' should be so much higher than 'non-' and 'partial' translations put together.

\section{The dynamics of 'non-,' 'partial' and 'full/near-full' translation.}

The following table contains information on a selected list of translated titles ranging from 'non-' to 'partial' to 'full/near-full' translations that have occurred in the broad Chinese context covering the PRC and Hong Kong and Taiwan. The intention is to both provide an indication of what kind of literature tends to be censored in the PRC and a sample of how 'non-,' 'partial' and 'full/near-full' translations in the PRC are matched up with 'full/near-full' translations in Hong Kong and/or Taiwan. 
TABLE 1

Illustrative examples for the dynamics of 'non-,' 'partial' and 'full/near-full' translations

\begin{tabular}{|c|c|c|c|}
\hline \multicolumn{2}{|c|}{ Original work } & \multicolumn{2}{|l|}{ Chinese translation } \\
\hline Author & $\begin{array}{l}\text { Publication } \\
\text { information }\end{array}$ & In PRC & In Hong Kong and/or Taiwan \\
\hline $\begin{array}{l}\text { Richard C. } \\
\text { Bush and } \\
\text { Michael E. } \\
\text { O'Hanlon }\end{array}$ & $\begin{array}{l}\text { A War Like No Other: } \\
\text { The Truth About } \\
\text { China's Challenge to } \\
\text { America. Hoboken: } \\
\text { John Wiley \& Sons. } \\
2007 .\end{array}$ & Non-translation up till now. & $\begin{array}{l}\text { Full translation in Taiwan: } \\
\text { Buyiyang de Zhanzheng: Taiwan de } \\
\text { Xuanze, Zhongguo de Jiaolv, } \\
\text { Meiguo de Tiaozhan (不一样的战 } \\
\text { 争: 台湾的选择・中国的焦虑・美国 } \\
\text { 的挑战). Tr. by Lin Zongxian (林 } \\
\text { 宗宪译).Taipei: Goodness } \\
\text { Publishing House. } 2010 \text {. }\end{array}$ \\
\hline $\begin{array}{l}\text { Frank } \\
\text { Dikotter }\end{array}$ & $\begin{array}{l}\text { Mao's Great Famine: } \\
\text { The History of China's } \\
\text { Most Devastating } \\
\text { Catastrophe, } 1958-62 . \\
\text { London: Bloomsbury. } \\
2010 .\end{array}$ & Non-translation up till now. & $\begin{array}{l}\text { Full translations in Hong Kong } \\
\text { and Taiwan: Mao Zedong de } \\
\text { Dajihuang: 1958-1962 Nian de } \\
\text { Zhongguo Haojieshi (毛泽东的大 } \\
\text { 饥荒: 1958-1962年的中国浩劫史). } \\
\text { Tr. by Guo Wenxiang, Lu Shuping, } \\
\text { Chen Shan (郭文襄, 卢蜀萍, 陈山). } \\
\text { Hong Kong: New Century Media } \\
\text { \& Consulting Co. Ltd. 2011. New } \\
\text { Taipei City: INK Literary Monthly } \\
\text { Publishing Co. Ltd. 2012. }\end{array}$ \\
\hline $\begin{array}{l}\text { Richard } \\
\text { McGregor }\end{array}$ & $\begin{array}{l}\text { The Party: The Secret } \\
\text { World of China's } \\
\text { Communist Rulers. } \\
\text { London: Penguin. } \\
2010 .\end{array}$ & Non-translation up till now. & $\begin{array}{l}\text { Full translation in Taiwan: } \\
\text { Zhongguo Gongchandang } \\
\text { Bukeshuo de Mimi (中国共产党不 } \\
\text { 可说的秘密). Tr. by Le Wei-liang } \\
\text { (乐为良). Taipei: Linking } \\
\text { Publishing Company, Ltd. } 2011 .\end{array}$ \\
\hline Ross Terrill & $\begin{array}{l}\text { The New Chinese } \\
\text { Empire: And What It } \\
\text { Means for the United } \\
\text { States. New York: } \\
\text { Basic Books. 2003. }\end{array}$ & Non-translation up till now. & $\begin{array}{l}\text { Full translation in Taiwan: } \\
\text { Yi Zhong Diguo Dameng (一中帝国 } \\
\text { 大梦). Tr. by Yang Ming-wei (杨明 } \\
\text { 暐). Taipei: Ars Longa Press. } 2004 \text {. }\end{array}$ \\
\hline $\begin{array}{l}\text { Jostein } \\
\text { Gaarder }\end{array}$ & $\begin{array}{l}\text { Sophie's World. New } \\
\text { York: Phoenix House. } \\
1995 .\end{array}$ & $\begin{array}{l}\text { Partial translations: } \\
\text { Sufei de Shiji (苏菲的世界). } \\
\text { Tr. by Xiao Baosen (萧宝森). } \\
\text { Beijing: The Writers Press. } \\
\text { 1999. }\end{array}$ & $\begin{array}{l}\text { Full translations in Taiwan: } \\
\text { Sufei de Shijie(苏菲的世界). Tr. by } \\
\text { Wu Fengzhen (伍丰珍). New } \\
\text { Taipei City: Wooden Horse } \\
\text { Cultural Establishments Co. Ltd. } \\
\text { 2010. }\end{array}$ \\
\hline $\begin{array}{l}\text { Robert } \\
\text { Lawrence } \\
\text { Kuhn }\end{array}$ & $\begin{array}{l}\text { The Man Who } \\
\text { Changed China: the } \\
\text { Life and Legacy of } \\
\text { Jiang Zemin. New } \\
\text { York: Crown. } 2004 .\end{array}$ & $\begin{array}{l}\text { Partial translations: } \\
\text { Ta Gaibian le Zhongguo: } \\
\text { Jiangzemin Zhuan (他改变了 } \\
\text { 中国: 江泽民传). Tr. by Tan } \\
\text { Zheng, Yu Haijiang. (谈峥, 于 } \\
\text { 海江 ) Shanghai: .Shanghai } \\
\text { Translation Publishing } \\
\text { House. 2005. }\end{array}$ & $\begin{array}{l}\text { Zero translation in Hong Kong } \\
\text { and Taiwan. }\end{array}$ \\
\hline $\begin{array}{l}\text { Peter } \\
\text { Hessler }\end{array}$ & $\begin{array}{l}\text { River Town: Two } \\
\text { Years on the Yangtze. } \\
\text { New York: Harper } \\
\text { Perennial. 2001. }\end{array}$ & $\begin{array}{l}\text { Partial translations: } \\
\text { Jiang Cheng (江城). Tr. by Li } \\
\text { Xueshun (李雪顺). Shanghai: } \\
\text { Shanghai Translation } \\
\text { Publishing House. } 2012 \text {. }\end{array}$ & $\begin{array}{l}\text { Full translations in Taiwan: } \\
\text { Xiaoshizhong de Jiangcheng: Yiwei } \\
\text { Xifang Zuojia zai Changjiang } \\
\text { Gucheng Tansuo Zhongguo (消失中 } \\
\text { 的江城; 一位西方作家在长江古城 } \\
\text { 探索中国). Tr. by Wu Mei Zhen } \\
\text { (吴美真). New Taipei City: Gusa } \\
\text { Publishing. 2012. }\end{array}$ \\
\hline
\end{tabular}




\begin{tabular}{|c|c|c|c|}
\hline $\begin{array}{l}\text { Vladimir } \\
\text { Nabokov }\end{array}$ & $\begin{array}{l}\text { Lolita. Paris: The } \\
\text { Olympia Press. } 1955 . \\
\text { (The version used in } \\
\text { this study being: } \\
\text { Lolita, edited with } \\
\text { preface, introduction, } \\
\text { and notes by Alfred } \\
\text { Appel, Jr. New York: } \\
\text { Vintage Books. 1991.) }\end{array}$ & $\begin{array}{l}\text { At least } 9 \text { translations were } \\
\text { made in the PRC after the } \\
\text { Cultural Revolution, } 8 \text { of } \\
\text { which were partial, } \\
\text { including: Luolita: Duoluo yu } \\
\text { Bingtai de Ai (罗丽塔:埅落与 } \\
\text { 病态的爱). Tr. by Hua Ming } \\
\text { and Ren Shengming (华明, 任 } \\
\text { 生名). Shijiazhuang: The } \\
\text { Hebei People's Publishing } \\
\text { House. 1989. } \\
\text { Luolita: Confessions of a } \\
\text { Widower (罗丽塔: 鲴夫忓悔 } \\
\text { 录). Tr. by Liu Lizhi (刘励志). } \\
\text { Hohhot: Inter Mongolia } \\
\text { Culture Publishing House. } \\
\text { 1994. Luolita: Yige Zhongnian } \\
\text { Nanren de Bulunzhilian (洛 } \\
\text { 丽塔: 一个中年男人的不伦之 } \\
\text { 恋). Tr. by Yu Xiaodan and } \\
\text { Liao Shiqi (于晓丹, 廖世奇). } \\
\text { Changchun: The Times Art } \\
\text { and Literature Press. 1997. } \\
\text { Full translation: Luolita (洛 } \\
\text { 丽塔). Tr. by Zhu Wan (主 } \\
\text { 万). Shanghai: Shanghai } \\
\text { Translation Publishing } \\
\text { House. 2005. }\end{array}$ & $\begin{array}{l}\text { Full translations in Taiwan: } \\
\text { Luolita (洛丽塔). Tr. by Huang } \\
\text { Jianren (黄建人). Taipei: Lin Yu } \\
\text { Cultural Enterprise Co. Ltd. } 1993 . \\
\text { Luolitai (罗丽泰). Tr. by Huang } \\
\text { Xiuhui (黄秀慧). Taipei: The } \\
\text { Prophet Press. 2000. Luolita (夢莉 } \\
\text { 塔). Tr. by Chen Jinhui (陈锦慧). } \\
\text { Taipei: The Sun Colour Culture } \\
\text { Publishing Co. Ltd. 2011. }\end{array}$ \\
\hline Pearl Buck & $\begin{array}{l}\text { The Good Earth. New } \\
\text { York: John Day Co. } \\
\text { 1931. (The version } \\
\text { used in this study } \\
\text { being: The Good } \\
\text { Earth. } \\
\text { Harmondsworth, } \\
\text { Middlesex: Penguin } \\
\text { in association with } \\
\text { Methuen. 1960) }\end{array}$ & $\begin{array}{l}\text { Non-translations between } \\
1949-1980 \text { s, as no } \\
\text { translations were allowed to } \\
\text { be made, and the pre-1949 } \\
\text { versions were banned. } \\
\text { Full/near-full translation: } \\
\text { Dadi (大地). Tr. by Wang } \\
\text { Fengzhen and Ma Chuanxi } \\
\text { (王逢振、马传禧). Guilin: } \\
\text { The Lijiang Press. 1988. }\end{array}$ & $\begin{array}{l}\text { Full translations: Dadi (大地). Tr. } \\
\text { by Xu Xiaomei (许小美). Hong } \\
\text { Kong: The Hung Kwong Book } \\
\text { Store. 1997. Dadi (大地). Tr. by Ma } \\
\text { Zhen (马真). Taipei: The } \\
\text { Singkuangbook Pres. } 1992\end{array}$ \\
\hline James Joyce & $\begin{array}{l}\text { Ulysses. New York: } \\
\text { Random House. } 1961 .\end{array}$ & $\begin{array}{l}\text { Non-translation before } \\
\text { Cultural Revolution but full } \\
\text { translation after: Youlixisi } \\
\text { (尤利西斯). Tr. by Xiao Qian } \\
\text { and Wen Jieruo (萧干,文洁 } \\
\text { 若). Nanjing: The Yilin } \\
\text { Publishing House. 1994. } \\
\text { Youlixisi(尤利西斯). Tr. by } \\
\text { Jin Di (金堤). Beijing: The } \\
\text { People's Literature } \\
\text { Publishing House. } 1994 .\end{array}$ & $\begin{array}{l}\text { Zero translation till the PRC } \\
\text { versions were republished in } \\
\text { Taiwan: Youlixisi(尤利西斯). } \\
\text { Tr. by Xiao Qian and Wen Jieruo } \\
\text { (萧干,文洁若). Taipei: The Owl } \\
\text { Publishing House Co. Ltd. } 1999 . \\
\text { Youlixisi (尤利西斯). Tr. by Jin Di } \\
\text { (金堤). Taipei: The Chiu Ko } \\
\text { Publishing Co.Ltd. } 2005 .\end{array}$ \\
\hline $\begin{array}{l}\text { Aldous } \\
\text { Huxley }\end{array}$ & $\begin{array}{l}\text { Brave New World: a } \\
\text { novel. Garden City, } \\
\text { N.Y.: Doubleday, } \\
\text { Doran \& company, } \\
\text { inc. } 1932 .\end{array}$ & $\begin{array}{l}\text { Non-translation before } \\
\text { Cultural Revolution but full } \\
\text { translation after: Meili } \\
\text { Xinshijie (美丽新世界). Tr. by } \\
\text { Li Li (李黎). Guangzhou: } \\
\text { Huacheng Publishing House. } \\
\text { 1987. Meimiao de Xinshijie } \\
\text { (美妙的新世界). Tr. by Sun } \\
\text { Fali (孙法理). Nanjing: The } \\
\text { Yilin Publishing House.2000. }\end{array}$ & $\begin{array}{l}\text { Full translations in Taiwan: } \\
\text { Taiwan: Meili Xinshijie (美丽新世 } \\
\text { 界). Tr. by Meng Xiangsen(孟祥 } \\
\text { 森). Taipei: Lauréat Publications. } \\
\text { 1994. Meili Xinshijie(美丽新世界). } \\
\text { Tr. by Li Li(李黎). Taipei: Zhiwen } \\
\text { Publishing House. } 2001 \text {. }\end{array}$ \\
\hline
\end{tabular}




\begin{tabular}{|c|c|c|c|}
\hline $\begin{array}{l}\text { George } \\
\text { Orwell }\end{array}$ & $\begin{array}{l}\text { Animal Farm. Essex, } \\
\text { England: Longman. } \\
1945 .\end{array}$ & $\begin{array}{l}\text { Non-translation before } \\
\text { Cultural Revolution but full } \\
\text { translation after: More than } \\
10 \text { full translations have } \\
\text { appeared in the PRC, } \\
\text { between 1989-2013 } \\
\text { including: Dongwu } \\
\text { Nongchang (动物农场). Tr. by } \\
\text { Fang Yuanwei (方元伟). } \\
\text { Shanghai: The Shanghai } \\
\text { Translation \& Publishing } \\
\text { Company. 1989. } \\
\text { Dongwu Nongchang(动物农 } \\
\text { 场). Tr. by Sun Zhongxu(孙仲 } \\
\text { 旭). Nanjing: Nanjing } \\
\text { University Press. } 2013 \text {. }\end{array}$ & $\begin{array}{l}\text { Full translations in Taiwan: } \\
\text { Dongwu Nongzhuang(动物农庄). } \\
\text { Tr. by Chen Xieqiao (陈枻樵). } \\
\text { Taipei: Rye Field Publishing Co. } \\
\text { 1974. Dongwu Nongzhuang(动物农 } \\
\text { 庄). Tr. by Kong Fanyun (孔繁云). } \\
\text { Taipei: Zhiwen Publishing House. } \\
\text { 1998. }\end{array}$ \\
\hline
\end{tabular}

It must be emphasised that the data provided in this table is but a selected list of samples from among the large pool of data collected so far by the above-mentioned research project. Although the table may be easily expanded, if necessary, with more titles and more detailed information of the given titles, the current examples should be interesting and adequate enough indicators of the kind of literature that may most likely fall into the categories of 'non-' and 'partial' translations, as well as the kind of literature that may be deemed to be 'untranslatable' before but 'fully/nearly-fully translatable' after. As such, they could serve as a reliable basis on which to examine how, on a macro as well as micro level, censorship- and/or self-censorship-affected 'partial' and 'non-' translations are related to unaffected 'full/near-full' translations in the Chinese context of the PRC. To substantiate this point, a more in-depth discussion of some of the examples from the table follows below.

Discussion. Briefly stated, what prevented or hindered the translation in the PRC, whether fully or partly, of the works listed in the above table was all because, in one way or another, the given works were not in keeping with existing Chinese constitutional laws (a point to be elaborated further below). Specific reasons may, however, be varied. Take for example Bush and O'Hanlon's A War Like No Other: The Truth About China's Challenge to America (2007), Dikotter's Mao's Great Famine: The History of China's Most Devastating Catastrophe, 1958-62 (2010) and McGregor's The Party: The Secret World of China's Communist Rulers (2010), which are all strictly censored, 'non-translations' in the PRC even today. What causes Bush and O'Hanlon's work to be a forbidden work is that it is full of talk on how in 20 years' time China may become the world's second super power and may pose severe challenges to the USA and the neighbouring countries in the region. From the perspective of the Chinese government, such talk is absolutely politically incorrect and unacceptable. In the case of Dikotter, what makes the work a prohibited piece for translation is the way in which it wrote about "Mao's Great Famine" of the late 1950s and early 1960s. That catastrophic famine has all along been described by the Chinese government as "The Three-Year Natural Disaster," whose death toll has never been officially disclosed and there has never been public discussion of who should be responsible for the catastrophe. Therefore, any account different from the government's, such as the harshly critical one provided in Dikotter, is absolutely prohibited. Likewise, in The Secret World of China's Communist Rulers, the author described present-day China as an emerging "empire" which tolerates no opposing voices and criticised it for not 
properly handling its problems and crises such as the SARS in 2003. This is of course not a welcome description to the Chinese government - even the critical overtone of the book title would be sufficient enough for the entire book to be censored as 'absolutely not translatable.'

For works which were not deemed as entirely objectionable in the political or ideological sense, such as Kuhn's The Man Who Changed China: the Life and Legacy of Jiang Zemin (2004) and Hessler's River Town: Two Years on the Yangtze (2001) as listed above, censorship or self-censorship was often exercised on part of the content. For example, about 5 percent of Kuhn's Jiang Zemin was deleted which concerned such politically sensitive issues as the June $4^{\text {th }}$ events in Tiananmen Square, the collapse of the Soviet Union, the Sino-North Korea relations and Tibetan Independence. Similarly, the PRC version of Hessler's River Town was partly censored where the June $4^{\text {th }}$ events in Tiananmen Square were described. (Interestingly, these omissions were all described by the author on his own homepage: http://peterhessler.net/).

As noted both earlier on and in Table 1 above, a great many foreign (especially Western) classics used to be 'non-translations' (including banned originals and suppressed translations) before and during the Cultural Revolution, e.g., Animal Farm (Orwell 1945), Lolita (Nabokov 1955) and Ulysses (Joyce 1922). The reason why Animal Farm had all along been a 'non-translation' in the PRC before and during the Cultural Revolution was obviously the author's sarcastic attack on communism (even though it was of the Soviet type), which, in turn, was against the political ideology of the Chinese Communist Party. The reason why Lolita was not allowed to be translated before, not even in a partial form, was that it was considered a morally 'bad' novel with its descriptions and narrations of a lot of 'obscene' and 'abnormal' scenes. And the reason why Ulysses was not translated into Chinese till 1994 seemed to be twofold: First, because no one seemed really well exposed to the Western 'stream of consciousness' school of literary creation; and therefore, secondly, the work was blindly criticised by the 'proletarian' Party line of 'serving the literary interests of the ordinary masses of the people' as bragging its 'decadent, bourgeois ideology.' However, after the Cultural Revolution ended, and with it the ultra-leftist political and ideological line of the Chinese Communist Party and the Chinese Government, censorship on foreign works and their translations was relaxed. According to an earlier study by this author (2015: 334), most Western works that had been categorised as 'untranslatable,' 'bourgeois' or 'anti-communist'/'anti-socialist' and even 'antiChina,' have all gradually found their way into the Chinese translated book market. Though there remain aspects of translational censorship that are change-resistant in the PRC, which would in one way or another result in 'non-translations,' it is nonetheless arguably true that in the China of today it would not be difficult to find a Chinese translation of any of the most important foreign literary titles, especially those written in the world's major languages, provided of course that they were of interest to translators and there was a potentially large enough readership. And this indeed explains why the contrastive figures presented in the pie chart of Fig. 1 are, quite truthfully, an overwhelming $97 \%$ for 'full/near-full translations' and 'partial translations' combined over a rather small $3 \%$ for 'non-translations.' 


\section{Further case analysis}

To illustrate the points further, let us examine some specific examples below that are culled from three well-known (self-)censorship-affected translations in the PRC, i.e., those of On China (Kissinger 2011), Lolita (Nabokov 1991) and The Good Earth (Buck 1960), in Tables 2, 3 and 4 respectively. The reason why these texts are chosen is not only that their translations are very well known to the Chinese reading public, but also, as explained earlier on in Section 3, they can in some ways be regarded as representative cases of shifting degrees of translatorial commitment, i.e., cases where there are interesting examples of censorship- or self-censorship-driven translational omissions or modulations. In discussing the examples, attention is directed to exactly where and how such omissions and changes are made. Limited by space, we will only select and discuss two examples from each book, with each example comprising the English ST and its Chinese TT(s) plus an English back-translation (made by this author) for reader comprehension of what is conveyed in the Chinese translations, followed by a brief commentary on the translator's work. An overall summary discussion will follow at the end.

TABLE 2

On China (Kissinger 2011). Translation by Lin Hua, Yang Yunqin and Zhu Jingwen (胡利平, 林华, 杨韵琴, 朱敬文) (2012). ${ }^{17}$

\begin{tabular}{|c|c|c|}
\hline ST1 & TT1 & Commentary \\
\hline $\begin{array}{l}\text { On September 9, 1976, Mao } \\
\text { succumbed to his illness, } \\
\text { leaving his successors with his } \\
\text { achievements and premonitions, } \\
\text { with the legacy of his } \\
\text { grandiosity and brutality, of } \\
\text { great vision distorted by } \\
\text { self-absorption. (p. 319) (All } \\
\text { highlighting underlines in both } \\
\text { the STs and TTs are mine.) }\end{array}$ & $\begin{array}{l}\text { 1976年9月9日毛泽东病逝, 给接 } \\
\text { 班人留下了他的功业和告诫, 留 } \\
\text { 下了他的豪情和他的远见卓 } \\
\text { 识。(Back-translation: On } 9 \\
\text { September 1976, Mao Zedong } \\
\text { passed away from illness, } \\
\text { leaving his successors with his } \\
\text { achievements and premonitions, } \\
\text { with the legacy of his } \\
\text { grandiosity and great vision.) } \\
\text { (p. 315) }\end{array}$ & $\begin{array}{l}\text { Although it is the official } \\
\text { resolution adopted by the ruling } \\
\text { Communist Party at one of its } \\
\text { congresses that Mao was " } 70 \% \\
\text { correct and } 30 \% \text { wrong in his } \\
\text { leadership of the Party" whereby } \\
\text { open criticism of him is not as } \\
\text { strictly forbidden now as it used } \\
\text { to be, such heavily pejorative } \\
\text { descriptions of Mao or his } \\
\text { endeavours as "his brutality" } \\
\text { (and, to a lesser extent, “... } \\
\text { distorted by self-absorption") } \\
\text { are nevertheless still not } \\
\text { acceptable to the authorities, } \\
\text { hence omitted from the TT. }\end{array}$ \\
\hline ST2 & TT2 & Commentary: \\
\hline $\begin{array}{l}\text { in 1950, upon the North Korean } \\
\text { invasion of the South, President } \\
\text { Truman moved the Seventh } \\
\text { Fleet into the Taiwan Strait, } \\
\text { forestalling an attempt by the } \\
\text { new government on the } \\
\text { mainland to reconquer Taiwan. } \\
\text { (p. 98) }\end{array}$ & $\begin{array}{l}\text { 1950年朝鲜战争爆发, 杜鲁门总 } \\
\text { 统把美国第七舰派往台湾海 } \\
\text { 峡, 防止中国政府解放台湾. } \\
\text { (Back-translation: In the year of } \\
1950 \text { when the Korean War } \\
\text { broke out, President Truman } \\
\text { moved the Seventh Fleet into } \\
\text { the Taiwan Strait to prevent the } \\
\text { Chinese government from } \\
\text { liberating Taiwan.) (p. 91) }\end{array}$ & $\begin{array}{l}\text { Expressions in the ST such as } \\
\text { "the North Korean invasion of } \\
\text { the South" and "reconquer } \\
\text { Taiwan" are obviously part of } \\
\text { the jargons of the U.S.A., which } \\
\text { do not concur with those of the } \\
\text { Chinese, hence modulated in } \\
\text { the TT to their 'politically } \\
\text { correct' forms that can pass } \\
\text { government censorship in the } \\
\text { PRC. }\end{array}$ \\
\hline
\end{tabular}


TABLE 3

Lolita (Nabokov 1955/1991). Translated by Zhu Wan (主万) (2005) and Huang Jianren (黄建人) (1993) respectively. ${ }^{18}$

\begin{tabular}{|c|c|c|c|}
\hline ST3 & TT3a & TT3b & Commentary \\
\hline $\begin{array}{l}\text { And what is most } \\
\text { singular is that she, } \\
\text { this Lolita, my } \\
\text { Lolita, has } \\
\text { individualized the } \\
\text { writer's ancient } \\
\text { lust, so that above } \\
\text { and over } \\
\text { everything there is } \\
\text { - Lolita. (p. } 44-45)\end{array}$ & $\begin{array}{l}\text { 最特别的是她, 这个洛 } \\
\text { 丽塔, 我的洛丽塔, 使 } \\
\text { 得作者古老的欲望具 } \\
\text { 有个人的特色, 于是在 } \\
\text { 所有一切之上, 只 } \\
\text { 有一一洛丽塔。 (p. 69) } \\
\text { (Back-translation: ... } \\
\text { [the writer's] age-old } \\
\text { desire ....) }\end{array}$ & $\begin{array}{l}\text { 非比寻常的是, 这个洛丽 } \\
\text { 塔, 我的洛丽塔, 唤醒了我 } \\
\text { 深埋已久的性欲, 于是高于 } \\
\text { 万物之上的是一一洛丽 } \\
\text { 塔。 (p. 67) (Back- } \\
\text { translation: ... [my] } \\
\text { long- and deep-hidden } \\
\text { sexual desire ...) }\end{array}$ & $\begin{array}{l}\text { "([T]he writer's) ancient } \\
\text { lust" is rendered as "(the } \\
\text { writer's) age-old desire" in } \\
\text { TT3a, which somewhat } \\
\text { dilutes the 'sexual } \\
\text { connotation' imbedded in } \\
\text { the original, and such a } \\
\text { modulation seems to have } \\
\text { resulted from a self- } \\
\text { censored act of translation } \\
\text { against the backdrop of an } \\
\text { assumed 'conservative' } \\
\text { PRC society. In contrast, } \\
\text { such a restriction is not } \\
\text { found in TT3b. }\end{array}$ \\
\hline ST4 & TT4a & TT4b & Commentary \\
\hline $\begin{array}{l}\text { the clean-cut, } \\
\text { glossy-haired, } \\
\text { shifty-eyed, } \\
\text { white-faced young } \\
\text { beasts in loud } \\
\text { shirts and coats, } \\
\text { vigorously, almost } \\
\text { priapically } \\
\text { thrusting out tense } \\
\text { thumbs to tempt } \\
\text { lone women or } \\
\text { sadsack salesmen } \\
\text { with fancy } \\
\text { cravings. (p. 159) }\end{array}$ & $\begin{array}{l}\text { 整洁好看、头发溜光、 } \\
\text { 目光栬诈、脸色雪白的 } \\
\text { 浮浪子弟, 他们穿着花 } \\
\text { 哨的衬衫和上衣, 有力 } \\
\text { 地、几乎是冲动地伸出 } \\
\text { 紧张的大拇指, 用种种 } \\
\text { 异想天开的恳求方式引 } \\
\text { 诱孤身女子或不中用的 } \\
\text { 推销员。(p. 250) } \\
\text { (Back-translation: } \\
\text { almost impulsively } \\
\text { thrusting out tense } \\
\text { thumbs ...or incapable } \\
\text { salesmen ... }\end{array}$ & $\begin{array}{l}\text { 干净利落、头发油光、眼珠 } \\
\text { 滴流转的小白脸们, 花里 } \\
\text { 胡哨的衬衫和外衣, 精力 } \\
\text { 充沛, 像显示他的男性性 } \\
\text { 感似的伸出坚得笔直的大 } \\
\text { 拇指, 勾引哪个寂寞的女 } \\
\text { 赶路人, 或哪个具有某种 } \\
\text { 特殊爱好的性无能推销 } \\
\text { 员。 (p. 204) (Back- } \\
\text { translation: ... [as if to } \\
\text { show] his masculine } \\
\text { sexuality by thrusting out } \\
\text { tense upright thumbs...or } \\
\text { sexually impotent } \\
\text { salesmen) }\end{array}$ & $\begin{array}{l}\text { The ST "priapically" } \\
\text { carries a clear association } \\
\text { with the male organ (i.e., } \\
\text { the penis) but a faithful, } \\
\text { literal translation (as partly } \\
\text { done with TT4b) would } \\
\text { seem quite a taboo in the } \\
\text { PRC context even today, } \\
\text { hence a self-censored } \\
\text { modulation on the part of } \\
\text { the translator in TT4a. The } \\
\text { same explanation is also } \\
\text { true of TT4a's rendering of } \\
\text { "sadsack" from a specific } \\
\text { contextual meaning of } \\
\text { "[sexually] impotent" (as } \\
\text { so rendered in TT4b) into a } \\
\text { rather generic "incapable" } \\
\text { in TT4a. }\end{array}$ \\
\hline
\end{tabular}

TABLe 4

The Good Earth (Buck 1960/1960). Translated by Wang Fengzhen and Ma Chuanxi (王逢振, 马传禧) (1998). ${ }^{19}$

\begin{tabular}{|c|c|c|}
\hline ST5 & TT5 & Commentary \\
\hline $\begin{array}{l}\text { Moreover, who has heard of a } \\
\text { pretty slave who was virgin in a } \\
\text { wealthy house? All the young } \\
\text { lords have had their fill of her. It } \\
\text { is better to be first with an ugly } \\
\text { woman than the hundredth } \\
\text { with a beauty. Do you imagine a } \\
\text { pretty woman will think your } \\
\text { farmer's hands as pleasing as the } \\
\text { soft hands of a rich man's son, } \\
\text { and your sun-black face as } \\
\text { beautiful as the golden skin of } \\
\text { the others who have had her for } \\
\text { their pleasure? (p. } 21 \text { ) }\end{array}$ & $\begin{array}{l}\text { TT5再说, 谁听说过有钱人家的 } \\
\text { 漂亮Y头会是个黄花囯女? 那些 } \\
\text { 少爷们早把她玩够了。你想想 } \\
\text { 看,一个漂亮女人会觉得你这庄 } \\
\text { 稼人的手同阔少爷柔软的手一 } \\
\text { 样舒服? 你那晒黑的脸与玩她的 } \\
\text { 那些人的金黄色的皮肤一样漂 } \\
\text { 亮? (p. 8) (The source line “It is } \\
\text { better to be first with an ugly } \\
\text { woman than the hundredth } \\
\text { with a beauty" is completely left } \\
\text { out untranslated.) }\end{array}$ & $\begin{array}{l}\text { The omission seems to have } \\
\text { resulted from an act of the } \\
\text { translator's self-censorship on } \\
\text { moral grounds: The source line } \\
\text { indicates a feudalistic, age-old } \\
\text { obsession of the Chinese male } \\
\text { for virgin women, and, if } \\
\text { literally rendered into Chinese, } \\
\text { may offend the modern reading } \\
\text { public, especially potential } \\
\text { readers holding a feminist world } \\
\text { outlook in a 'politically, } \\
\text { ideologically and morally } \\
\text { progressive' communist society } \\
\text { of the PRC. }\end{array}$ \\
\hline
\end{tabular}




\begin{tabular}{|c|c|c|}
\hline ST6 & TT6 & Commentary \\
\hline $\begin{array}{l}\text { This time she was long at labor } \\
\text { and when Wang Lung came } \\
\text { home at evening he found his } \\
\text { father standing at the door and } \\
\text { laughing and saying, } \\
\text { "An egg with a double yolk this } \\
\text { time!" (p. 144) }\end{array}$ & $\begin{array}{l}\text { 这次她生的时间很长。晚上王龙 } \\
\text { 回到家里时, 他看见父亲站在门 } \\
\text { 口笑着说: “这次是对双 } \\
\text { 生!”(p. 127) (Back-translation: } \\
\text { A pair of twins this time.) }\end{array}$ & $\begin{array}{l}\text { The metaphor of comparing a } \\
\text { woman giving birth to children } \\
\text { to a hen producing eggs may be } \\
\text { viewed as 'politically incorrect' } \\
\text { language for women in the PRC } \\
\text { context, hence its modulation to } \\
\text { a non-metaphorical expression } \\
\text { to avoid potential offence } \\
\text { against the general Chinese } \\
\text { reading public. }\end{array}$ \\
\hline
\end{tabular}

From the examples, we can see that the causes for a 'non-,' a 'partial' or a 'full/ near-full' translation to happen in the PRC are relatively straightforward: in the first scenario, the overall content of the work is deemed by government censors and/or the self-censor of the translator or publisher as 'anti-Chinese constitutional laws' (including 'anti-China,' 'anti-top Chinese leadership,' 'anti-Chinese people,' 'antiCommunist,' 'subversive,' 'obscene,' 'immoral,' 'spreading inter-ethnic hatred,' 'instigating violence,' etc.), hence 'untranslatable' and 'unpublishable'; in the second, the content of the text is of a 'translatable' nature in principle but some of the content is somehow 'politically or otherwise too sensitive' to be faithfully translated into Chinese; whilst in the third, everything about a given source text is 'fully/near-fully translatable,' as it is either entirely or mostly 'harmonious' in relation to Chinese laws. As we have noted before (Tan 2015: 323-324), the PRC laws on censorship of translation and publication are stipulated in the country's Ordinance on Publishing, i.e., “Regulations on the Administration of Publication” (出版管理条例), of which Articles 25 and 26 explicitly spell out what material (translated material included) is not permitted to be published in China. Though that Ordinance was not formally adopted till 1997, the country has nonetheless always exercised censorship over translation and publication since 1949 and the fundamental principles have basically remained the same across the various periods, ranging, for example, from the post1949 to the post-Cultural Revolution and further to the post-1989 times. What may have evolved or changed are, however, the ways in which those fundamental principles are interpreted or the ways in which the given censorial policies are prioritized, and, in turn, their interpretations and priorities always change with the changing times. For example, one of the fundamental principles guiding censorship in the PRC is that no translations shall be allowed that are 'anti-China,' but the connotations of this have varied drastically over time, and so has government censors' tolerance of what is regarded as 'anti-China.' A case in point is the changing status of The Good Earth from a prohibited, 'anti-China' and 'anti-Chinese people' nontranslation in the pre-Cultural Revolution as well as during the Cultural Revolution periods, to a book that is more or less 'fully translatable' (that is, except for some isolated, 'less translatable' sentences or phrases as shown in TT5 and TT6 above), a book by someone who was a 'friend' to China and the Chinese people, rather than an enemy as she was once regarded as (see discussion in Section 4). The same kind of interpretational dynamics is also true of such other designations as 'anti-Communist,' 'anti-Chinese Constitution,' 'politically subversive,' 'ideologically reactionary,' 'morally unhealthy,' 'anti-harmonious society' and so on and so forth (see Section 3). 
To follow on this last point, we may further say that, in the Chinese context (as is indeed also true of all contexts, past or present, under a socialist/communist, authoritarian or under a capitalist, democratic system), censorship of certain types of literature and literary translation is both a 'constant' and a 'variable' phenomenon. It is a 'constant' because it exists in all contexts and at all times. For example, Clauses 2 and 3 of Article 25 of the Chinese Constitution read: "No publications [including translations] shall include ... (2) contents that endanger national unity, sovereignty or territorial integrity; [and] (3) contents that disclose secrets of the State, endanger national security, or damage national honour or interests." Any violation of these restrictions will be deemed to be a violation of the constitutional law and will therefore be subjected to punishment. Obviously, such 'national security' issues also apply in the contexts of other countries including those that are professedly the most democratic in the world such as the USA: the famous Edward Snowden case is a good example where the former intelligence contractor was charged by the American government with espionage and theft for revealing U.S. National Security Agency information to journalists. On the other hand, of course, as said above, the interpretation of what constitutes a violation of the constitutional laws, or what constitutes censorable material, as well as the intensity with which to prioritize the implementation of the 'constitutional laws' or to enforce a punishment for violating them may vary with the times or with the circumstances, etc. and this is what is meant by the 'variable' characteristic of censorship in translation.

Another point worth special attention concerns the meaning of 'non-translations' in relation to 'translational omissions/deletions' and the (self-)censorshipmotivated modulations that are made in given translation projects. In the broad sense, a 'non-translation' may mean both an entire text being cast into the 'nontranslation' category, such as the first four items listed in Table 1 under the heading of the PRC, and a part of a given text (e.g., a passage, a sentence or a word of that text) that has been censored and/or self-censored. In this latter case, a 'non-translation' is the same as a '(translational) omission/deletion' in conventional terminology. Of the two types of 'non-translation,' the second is often the more engaging to the translation or TS researcher, for it is here that government censorship and the translator's (publisher's, editor's or even commissioner's) own censorship tend to join forces to affect a given translation, and it is here that some of the most interesting controversies about censorship and self-censorship in translation may arise, such as in the case of the PRC Chinese version of Hillary Clinton's Living History (see discussion, for example, in Chan 2007; Chang 2008; Tan 2015).

Equally interesting and challenging to the translator and TS scholar are the various kinds of modulations that may need to be made in translation under the visible as well as invisible hand of censorship and self-censorship, e.g., the changes (as shown in the relevant examples above in the translation of On China (TT2)) of "[upon] the North Korean invasion of the South" and "[forestalling an attempt by the new government on the mainland] to reconquer Taiwan" into "[when] the Korean War broke out” (朝鲜战争爆发) and “[to prevent the Chinese government from] liberating Taiwan” ([防止中国政府]解放台湾); and in Lolita of “[the writer's] ancient lust” into “[the writer's] age-old desire” (古老的欲望)(TT3a) and “priapically [thrusting out tense thumbs]" into “impulsively [thrusting out tense thumbs]" (冲动地[伸 出紧张的大拇指])(TT4a) respectively. Clearly, as remarked in the relevant commen- 
taries above, these are not innocent changes but are changes made for a purpose, a purpose that may not necessarily be directly driven by government censorship but that must in one way or another be related to the socio-political or cultural/moral environment under which such changes are made. This kind of translator's self-initiated or self-censored modulations are certainly quite evident in how the name of the book is translated with some of the Chinese versions of Lolita. Instead of transliterating the title into a straightforward “洛丽塔” (or “Luolita” in Romanized Chinese pinyin), 3 out of the 9 PRC published translations have expanded the original Lolita into “罗丽塔: 阷落与病态的爱” (Luolita: Perverse and Morbid Love; Hua and Ren’s version [华明, 任生名译], 1989), “罗莉塔: 鲜夫忓悔录” (Luolita: Confessions of a Widower; Liu's version [刘励志译], 1994) and “洛丽塔: 一个中年男人的不伦之 恋” (Luolita: A Middle-aged Man's Immoral Love; Yu and Liao’s version [于晓丹, 廖 世奇译], 1997) respectively (See publication details of these translations in Table 1 in Section 5). The explanatory subtitles in these translations apparently all contained manipulated additions, which revealed the translators' moral attitude towards the storyline of the novel, partly as an effort to avoid potential conflict with rigid institutional (e.g., government or publishing house's) censorial position and partly to prepare the reading public (especially the more conservative part of it) not to be overly-shocked by what they are going to read in the story.

In view of all this, it may be true that, in the Chinese context, especially that of today when there is said to be an increasingly more liberal government position on censorship, the most intriguing challenges that the translator may be faced with do not come from rigid state or government censorship but the translator's (or the publisher's and editor's) own censorship out of various considerations, ranging from political, ideological, religious and ethical/moral to socio-cultural and even economic. This is particularly evidenced by a double-faceted fact: firstly, as shown by the statistics presented in the pie chart of Fig. 1 above, the percentages of overt 'nontranslations' and 'partial translations' that have existed in recent years in the PRC are both rather small, in contrast with an overwhelmingly large proportion of what can be categorised as 'full/near-full translations.' This may be viewed as an encouraging indication that government censorship on translation in the PRC today is continually on the decrease, and translators need not be too anxious whenever there are new finds of foreign literature to translate into the Chinese language. Secondly, if one carefully compares the target and source texts that are covered in this research, it would not be difficult to find that many of the so-called 'full/near-full translations,' including those which are considered so by the translators themselves, often include omissions and modulations in the various target texts which seem to be the result of the translator's 'deliberate interventions' (Bastin 2012), rather than the result of their 'innocent,' 'unintentional' behaviour. The examples provided in TT5 and TT6 above of Wang Fengzhen and Ma Chuanxi's 1988 translation of The Good Earth and Zhu Wan's 2005 version (TT3a and TT4a) of Lolita can clearly illustrate this point. In other words, self-censorship in translation seems to be an important inbuilt quality of the translator in the Chinese context of the PRC. Whether or not, and how or how much, this is going to change is definitely a worthy area for further research. 


\section{Conclusion}

Censorship in translation as a measure to filter or screen out potentially 'harmful' or 'subversive' foreign ideas results in the various forms of translation, ranging from 'non-' to 'partial' to 'full/near-full,' that we find in virtually every context, especially in contexts such as the Chinese where the censoring of literature for translation and publication is explicitly provided for by the nation's constitutional laws. What is most interesting about such contexts is the dynamic shifts between the various forms of translation, a dynamics determined by the fact that, in spite of the ubiquitous nature of censorship, the ways in which given censorial policies operate tend to change, both with the times and with the evolution of the socio-political system that conditions them. This point is amply proven by the shifting status of specific translations affected by the shifting degrees of censorship, through over 60 years of development since the founding in 1949 of the People's Republic of China, including the once absented translations of earlier times which, later on, were converted from 'non-' to 'partial' or 'full/near-full' translations amidst a politically more liberal environment (e.g., The Good Earth); those which started as 'non-translations' but then, likewise, became 'partial' or 'full/near-full' translations under the country's subsequently more relaxed implementation of its censorial policies (e.g., Nabokov's Lolita); and those which fall into the 'partial translations' category which bear the characteristics of 'their being basically circulable/translatable whilst containing contents that must be "weeded out" before actual circulation occurs' (e.g., Kissinger's On China and Hillary Clinton's Living History). By the same token, it may also be possible that certain members of the existing 'non-translations' category, such as those currently deemed as 'politically too sensitive' (e.g., Ross Terrill's The New Chinese Empire: And What It Means for the United States), may at some point in the future be converted into 'partial' or even 'full/near-full' translations.

Examination of such shifts in translational practice fully reveals the dynamic nature of translatorial commitment in connection with the change-resistant properties as well as the evolving priorities of translational censorship, and further leads on to the conclusion that the translator, especially one operating in the Chinese context of the PRC, is under the constant influence of censorial forces, both explicit and implicit, both visible and invisible. While the explicit and visible aspects of the forces, i.e., those which relate themselves primarily to overt state/government censorship, determine the general direction of the dynamic movement between 'non-' and 'partial' and 'full/near-full' translations, it is the implicit and invisible aspects, i.e., those residing in the translators themselves, that orient how the macro, overall censorial policies of the state/government constantly take effect, for example, via such 'deliberate interventions' of the translator as the politically, ideologically or otherwisemotivated modulations through the entire translation process.

\section{ACKNOWLEGEMENTS}

This paper derives from some of the research findings of the author's General Research Fund project supported by the Research Grants Council of Hong Kong (Project Number: GRF12407314). 


\section{NOTES}

1. Henry Kissinger (2011): On China. 2011. New York: Penguin Press. Chinese source: Hu Liping, Lin Hua, Yang Yunqin and Zhu Jingwen (胡利平, 林华, 杨韵琴, 朱敬文). (2012): 论中国, Beijing: China CITIC Press.

2. Vladimir Nabokov (1991): Lolita. Edited with preface, introduction, and notes by Alfred Appel, Jr. New York: Vintage Books. Chine sources: a) Zhu Wan (主万). (2005). 洛丽塔, Shanghai: Shanghai Translation Publishing House; b) Huang Jianren (黄建人). (1993). 洛丽塔, Taipei: Lin Yu Cultural Enterprise Co. Ltd.

3. Pearl Buck (1960): The Good Earth. Harmondsworth, Middlesex: Penguin in association with Methuen. Chinese source: Wang Fengzhen and Ma Chuanxi (王逢振, 马传禧). (1988). 大地, Guilin: Lijiang Publishing House.

4. Chinese original: ......但是, 作为西方人士, 作者在写作观点、素材取舍、思想方法、以及分析问题 的角度等方面, 有其自身的特点和局限性。由于是外国人, 不太可能对中国的事件一一正确理解, 所使用的材料也不可能完全可靠, 其见解难免带有主观随意性。为了保持书的原貌, 译者仅对过 于离奇之处作了适当的处理, 书中有些情节以及思想观点还有待于读者去甄别判断。同时, 对一 些不必要的注释进行了删减, 还增加了一些有助于中国读者更好理解该书内容的注释。

5. Chinese original: 司徒雷登对中国事务的种种叙述几乎都是片面的、歪曲的、因而十分反动, 但在 我们今天研究中美关系史、外国在华布道事业的虚伪性、美蒋勾结的历史和蒋王朝倒台的必然性 的时候, 作者却在其回忆录中从反面为我们提供了一些值得参考的数据。因此, 本书按原文照译, 只删节了马歇尔写的序、胡适写的导言和大段吹捧蒋介石的个别章节……

6. D.H. Lawrence (1928). Lady Chatterley's Lover. Garden City, N.Y.: Nelson Doubleday.

7. Chinese source: 饶述一 (译), 查泰莱夫人的情人, 上海: 北新书局, 1936.

8. Chinese source: 冯铁 (译), 查泰莱夫人的情人, 郑州: 河南文艺出版社, 2007.

9. Chinese source: 杨恒达, 杨婷 (译), 查泰莱夫人的情人, 北京: 燕山出版社, 2008 .

10. Chinese source: 雍穆贝勒 (译), 查泰莱大人的情人, 北京: 中国华侨出版社, 2009.

11. Chinese source: 黑马 (译), 查泰莱大人的情人 (双语版), 南京: 译林出版社, 2009; (单语版), 北京: 中央编译出版社, 2010.

12. Chinese source: 先子 (译), 查泰莱夫人的情人, 济南: 山东文艺出版社, 2010 .

13. Under the censorship system of the PRC, whether or not a given foreign work is allowed to be translated or imported is often determined by whether the given author is perceived as 'a friend' or 'a foe.' A study was conducted by Fang Kecheng (方可成) and published in the 3 March 2011 issue of 南方周末(The Nanfang Weekend), the most popular weekly newspaper in China with one of the largest circulations of 1.2 million copies per issue, on "Who are "the old friends of the Chinese people.” Fang researched all the issues between 1949-2010 of 人民日报 (The People's Daily), the most important daily newspaper in China which was ranked by UNESCO in 1992 as one of the top 10 newspapers in the world. He came up with some interesting findings on who have been 'officially' perceived by the Chinese government as 'old friends of the Chinese people' and how and why. He pointed out that the 'official' criteria with which to judge 'who are our friends' have, at least from 1949 up to the 1980s, been whether the people concerned were 'anti-imperialist,' 'anticolonialist' and 'anti-aggression' or whether they held a 'friendly' or 'sympathetic' attitude towards the undertakings of the Chinese people. Obviously, it was according to such standards that Pearl Buck was regarded over a long period of time as an 'unfriendly,' hence 'unwelcome,' figure: As Stirling (1983: 317) recounted (see also Liang's discussion in her doctoral thesis on Pearl Buck, 2011: 55), Buck wrote on a couple of occasions to the Chinese government in 1972 in the hope of obtaining a visa to visit China, but her application was bluntly rejected by the Chinese embassy to the USA who said: "[Dear Miss Pearl Buck,] Your letters have been duly received. In view of the fact that for a long time you have in your works taken an attitude of distortion, smear and vilification towards the people of new China and its leaders, I [Second Secretary of the embassy who issued the reply letter] am authorized to inform you that we cannot accept your request for a visit to China." Much to her disappointment and dismay, Buck died in 1973 without having had a chance to set foot on Chinese soil again after she left it in 1934 to live back in her home country of America. However, with the change of the times in the late 1970s and early 1980s and the abandoning of the ultra-leftist political and ideological line of the Chinese government, the 'foe' status formerly thrust on Buck was gradually removed. By the late 1980s, she was no longer a forbidden author and in 1988 her China trilogy of The House of Earth (including the 1938 Nobel Prize for Literature winner The Good Earth) was re-translated and published by the Lijiang Press (漓江出版社), the first time ever since 1949 . 
14. George Orwell (1945), Animal Farm: A Fairy Story. London: Penguin Books Ltd.

15. It must be mentioned that there was in fact an earlier Chinese translation of Animal Farm, made in 1948 by Ren Chiyu (任稚羽) and published by the Commercial Press in Shanghai. However, the social impact of that initial version on Chinese society was minimal because not many Chinese readers at the time were aware of the existence of the book or had any interest in whatever insinuation and satire the story might have towards [the Soviet Russian type of] socialism and communism. Moreover, hardly had there been time for the Chinese reading public to come to know what the book was all about when the publication environment in the country took a fundamental change with the founding in 1949 of the socialist state of the PRC. Consequently, exactly because of the satirical nature of the book at socialism and communism, and also much because of "the influence of a 'fraternal' Soviet Union (at least before close China-Soviet ties began to crumble towards the end of the 1950s)" (Tan 2015: 331), the book immediately submerged into a virtual 'non-translation' under the censorship system of the PRC, and this situation did not change until well into the 1980s, when in 1988 the first PRC version of Animal Farm appeared, co-made by Zhang Yi and Gao Xiaoxian (张毅, 高孝先) and published by the Shanghai People's Publishing House. That is why the translation of Animal Farm is treated here as a basically 'forward evolution' case of translation, unlike the case of D. H. Lawrence's Lady Chatterley's Lover and Pearl Buck's The Good Earth where there was a more 'circular' movement, so to speak, between translation and non-translation.

16. The full corpus of the project containing detailed information on the published translations (19492015) will be ready and made public after the project is completed in July 2017.

17. See Note 1 for detailed bibliographical information.

18. See Note 2 for detailed bibliographical information.

19. See Note 3 for detailed bibliographical information.

\section{REFERENCES}

Bastin, Georges L. (2012): Translators' deliberate intervention.” Seminar talk (6 Aug. 2012) at Centre for Translation, DLB 601, David C. Lam Building, Shaw Campus, Hong Kong Baptist University, Renfrew Road, Kowloon Tong

Billiani, Francesca (2007): Modes of Censorship and Translation: National Contexts and Diverse Media. Manchester: St. Jerome Publishing.

CHENG, Zongjia (程宗家译)(1982): 译者的话. 在华五十年一一司徒雷登回忆录 (Yizhede hua. Situ Leideng Huiyilu) [The translator's remarks. A translation of John Leighton Stuart's Fifty Years in China - The Memoirs of John Leighton]. Beijing: The Beijing Publishing House.

CHAN, Red (2007): One nation, two translations: China's censorship of Hillary Clinton's Memoir. In: Myriam SALAMA-CARR, ed. Translating and Interpreting Conflict. Amsterdam and New York: Rodopi. 119-131.

ChAng, Nam Fung (2008): Censorship in translation and translation studies in present-day China. In: Teresa SERUyA and Maria Lin Moniz, eds. Translation and Censorship in Different Times and Landscapes. Newcastle, UK: Cambridge Scholars Publishing. 229-240.

Escolar, Marisa (2011): Contaminating Conversions: Narrating Censorship, Translation, Fascism. Dissertation. Gradworks.umi.com.

FENG, Changhong (封长虹) (1990): 译者序. 周恩来传 (Yizhe xu. Zhou Enlai Zhuan) [The translator's preface. A translation of Dick Wilson's A Biography of Zhou En-lai]. Beijing: The People's Liberation Army Press.

Holman, Michael and BoAse-Beier, Jean (1999): Introduction. In: Jean BoAse-Beier and Michael Holman, eds. The Practices of Literary Translation: Constraints and Creativity. Manchester: St Jerome Publishing. 1-17.

LIANG, Zhifang (梁志芳)(2011): 翻譯與中國形象的自我建構一形象學理論視角下的《大地》中 譯研究, (Translation and self-construction of the China image-An imagological study of Chinese translations of Pearl Buck's China novel The Good Earth). PhD thesis. Hong Kong: Hong Kong Baptist University Library.

Merkle, Denise (2002): Presentation. In: Denise Merkle, ed. TTR: Traduction, terminologie, redaction. 15(2):9-18. 
Seruya, Teresa (2008): Foreword. In: Teresa Seruya and Maria Lin Moniz, eds. Translation and Censorship in Different times and Landscapes [electronic resource]. Newcastle, UK: Cambridge Scholars Publishing. xi-xix.

TAN, Zaixi (2015): Censorship in translation: the case of the People's Republic of China. Neohelicon: Acta comparationis litterarum universarum. 42(1):313-339.

- (2014): (Self-)censorship and the translator-author relationship: the case of full translation, partial translation, and non-translation in the Chinese Context. Asia Pacific Translation and Intercultural Studies. 1(3):192-209. 